\title{
LANDSCAPES AND ECOSYSTEMS IN DRAGOMAN MUNICIPALITY, WESTERN BULGARIA
}

DOI: https://doi.org/10.18509/AGB.2020.13

UDC: $911.52: 502.13(497.2)$

\section{Borislav Grigorov 1 , Kiril Vassilev², Assen Assenov ${ }^{1}$}

\author{
${ }^{1}$ Faculty of Geology and Geography, University of Sofia "St. Kliment Ohridski, Sofia, Bulgaria \\ ${ }^{2}$ Department of Plant and Fungal Diversity and Resources of the Institute of Biodiversity and Ecosystem Research \\ at the Bulgarian Academy of Sciences, Sofia, Bulgaria. \\ corresponding author: borislav.g.grigorov@gmail.com
}

submitted: 17.02 .2020

accepted: 25.04 .2020

published: 20.08 .2020

\begin{abstract}
The present investigation aims to uncover the landscape diversity in Dragoman Municipality, as well as the ecosystem types, which are representative for the territory. The interest towards this geographical area roots in its close proximity to the capital city of Sofia and the ongoing road works for the establishment of the "Europe" Motorway. It also represents a continuation of the study of the landscapes and ecosystem types in western direction. The mapping of the landscapes is based on the application of LANMAP 2 approach and the development of several GIS layers, consisting of main landscape components: lithology, relief, climate, soils and land cover. The ecosystem types are differentiated, based on the integration between CORINE Land Cover Dataset as of 2018 and the MAES Typology. The results are showing a final landscape map, consisting of 199 landscapes, representing by code symbols, as well as a map of seven different ecosystem types.
\end{abstract}

Keywords: landscapes, ecosystem types, LANMAP 2, MAES Typology.

\section{INTRODUCTION}

The interest towards the current investigation raised from a variety of geographical and ecological factors. Dragoman Municipality is located in an area, which is near to the capital city of Sofia. Therefore, the probability of intensive anthropogenic pressure is not to be underestimated. Moreover, the building of a major European Highway is undergoing at the current moment. The "Europe" Motorway is expected to pass near the village of Dragoman and to reach Kalotina border crossing. It is obvious that a major section of it will cross Dragoman Municipality, which undoubtedly will have a major impact on its landscapes. On the other hand the geographical location of the municipality, reaching the borderline between Bulgaria and Serbia - one economically underdeveloped region, alongside with the lack of high population density in the area, leads to the assumption that there have to be preserved landscapes of a more untouched character in the territory. Based on these and other geographical characteristics, a high diversity of natural complexes can be expected, rooting in the diverse interactions between the landscape components of the lithology, relief, climate, water, soil, vegetation and fauna.The analysis of the historical development of the landscape components and the investigation and classification of the present landscapes is a basis of the current investigation. A similar landscape study was carried in 2018 and published officially by in 2019 [6]. It is covering the geographical area of Mala Planina - a part of its Kamuka Ridge is located in the eastern section of Dragoman Municipality. Other landscape studies act as a basis of the present investigation, such as the studies in neighboring areas of Dragoman Municipality in Western Stara Planina [7], [8], [9], the scientific work "Landscape Geography of Bulgaria" [17], the study "Landscapes of Bulgaria - Spatial Structure" [15] and the dissertation of 
Cholakova [5].The differentiation of ecosystem types in the studied area is another task, that authors aim at accomplishing and they apply a certain typological approach. The Working Group for Mapping and Assessment on Ecosystems and their Services (MAES), following Action 5 of the EU Biodiversity strategy set an array of targets, among which are the economic importance and value of

\section{METHODOLOGY}

The integration of the system's approach is indispensable for the present landscape investigation. Terrain expeditions and observations were carried between the months of May and September, 2019 when more than 1000 mappings were conducted (Figure 1). The study area is located in the western part of the country and covers around 324 square kilometers. Dragoman Municipality is one of the 22 municipalities in Sofia Provinces and it takes 8 th place, considering its areal extent. The municipality takes a borderline area with the Republic of Serbia is located to the these services. The first and the second technical reports [10], [11] provided a broad analytical framework and indicators for mapping and assessment of biodiversity, ecosystem condition and ecosystem services, which are applied in the current investigation. This is not the first mapping of this type for Bulgaria and Nedkov [12] followed this approach in their study.

west of it. To the south and southwest are Breznik Municipality and Tran Municipality, while to the north and northeast is Godech Municiaplity. Dragoman Municipality's eastern and southeastern neighbors are Kostinbrod Municipality and Slivnitsa Municipality. The complexity of its relief roots in the various geomorphological formations. The mountains of Chepun and Viskyar are situated to the northeast and southwest, respectively, a restricted part of Mala Planina, and the Tri Ushi Ridge are to the east, while Sofia Valley and Burel Valley add even more fragmentation to the relief.

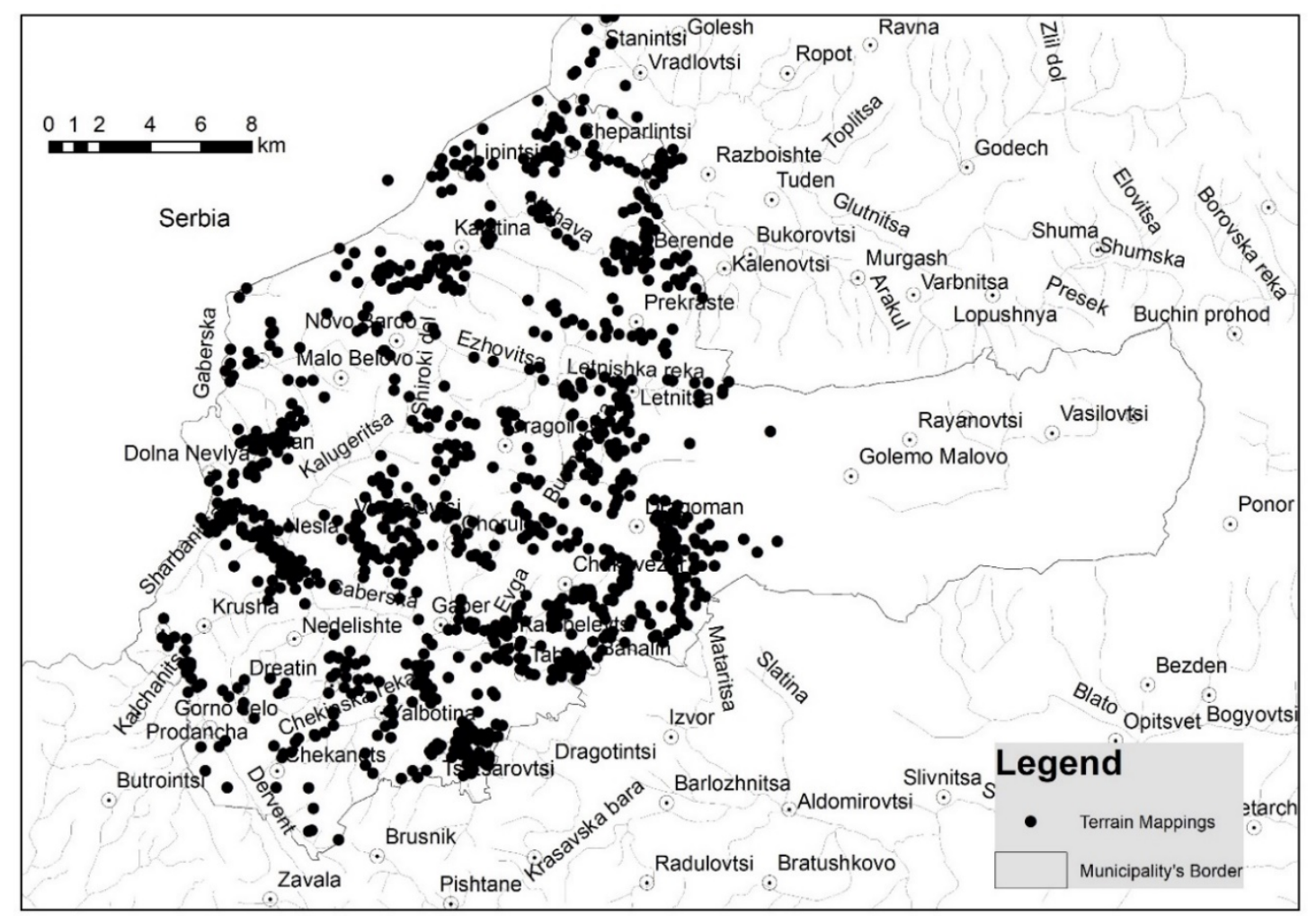

Figure 1. Terrain investigations in Dragoman Municipality.

The methodological approach of the study included several actions, consisting of observations, terrain research, and collection and processing of primary and secondary data. The hierarchical and genetic approaches were applied, as a foundation for the development of the classification system and the following principles of complexity, relative homogeneity, logical correctness and practical application were considered. The study uses the LANMAP 2 approach, developed as a system of the 
European landscapes by The European Landscape Character Initiative (ECLAI) [18]. The current investigation does not have the pretention to be the first in the territory of Bulgaria, applying LANMAP 2 for landscape mapping and it is a logical continuation of the landscape investigations in Mala Planina. In 2012 and in 2014 [1], [2], [3] studies were carried, applying this methodology in the territories of Strandzha, Central Stara Planina and the Rhodopes. These studies are a main methodological source for the investigation, concerning Dragoman Municipality, alongside with the application of the principle of "uniform spatial dimensionality" of the classification categories [13]. The landscape map of Dragoman Municipality represents an integration of different layers, carrying information about the main landscape

\section{RESULTS AND DISCUSSION}

The outcomes of the investigation are divided into two sections, covering the landscape diversity and the ecosystem types.

\section{Landscape diversity}

The application of the methodological approaches has led to the development of a full picture of the present day landscapes in Dragoman Municipality. A basis of the final landscape map of the municipality is the landscape classification, developed as a differentiation tool of the diversity of landscapes in the area. The minimum area of each mapped unit is 10 ha, following the compliance with the needs of a better comprehension of the map. The map is built by applying the software product ArcGIS 10.1 (Table 1) A quick glance at Table 1 provides a comprehensive perspective of the way the landscape map was built. The landscape classification system consists of a classification category or level of differentiation, a diagnostic criterion, a level of generalization and a symbol, which marks each of them. The classification category consists of seven taxonomical units or ranks. The largest unit of them is the Class (Level 1) and macromorphological particularities of Dragoman Municipality are its foundation. Two classes are to be considered: the class of mountainous landscapes, marked with " $\mathrm{M}$ " and the class of plains and hilly pre-mountainous landscapes, marked with "P". The second rank is components, in a GIS environment. These layers include data about the geology, relief, climate, soils, vegetation and other land cover types.

The ecosystem types of Dragoman Municipality are differentiated on the basis of the integration between MAES Typology and CORINE Land Cover Dataset 2018) [19] and the correspondence between CORINE Land Cover classes at level 3 with the ecosystem types at level 2. CORINE Land Cover classes were integrated with the ecosystem types at its level 2 and the investigated territory includes all ecosystem types of the terrestrial major ecosystem category. Information, concerning Dragoman Municipality, was extracted from the dataset and then modified in order to get the required results.

the Type, it covers Level 2 and Hydro-climatic conditions are the main diagnostic criterion.

By taking this into consideration, two types of landscapes can be distinguished - the first type covers landscapes with humid climate, marked with " $\mathrm{H}$ " and the second one consists of landscapes with wet subhumid climate „W“. Zonal and intrazonal vegetation is the diagnostic criterion for the Subtype or Level 3. Vegetation is marked only with one symbol - "V". Next is mezorelief, which covers the genus rank or level 4. Here, denudation levels without karst "I", denudation levels with karst „II“ and erosional and denudation landscapes „III“ can be distinguished, regarding the main processes in the formation of denudation levels. The group or level 5 covers the rock fundament. Landscapes of Dragoman Municipality are consisting of carbonate sedimentary rocks „,c“, non-carbonate sedimentary rocks „n“, magmatic and metamorphic rocks „,m“ and uncosolidated deposits „u“. The last two levels -6 and 7 are taken by soil types and land cover and they are representing their typical characteristics.

By applying these criteria for differentiation and classification and by vectorising the main layers with landscape components, the final landscape map was developed. The following lines present a distinguishment of the leading landscape components. 
Table 1. Factors and Criteria for Landspace Classification and Differentation.

\begin{tabular}{|c|c|c|c|}
\hline $\begin{array}{c}\text { Classification } \\
\text { Category/Level of } \\
\text { Differentiation }\end{array}$ & Diagnostic Criteria & Level of Generalization & Symbol \\
\hline \multirow{2}{*}{ Class (Level 1) } & \multirow{2}{*}{ Macromorphology } & Mountainous Landscapes & $\mathrm{M}$ \\
\hline & & Plains and hilly pre-mountainous Landscapes & $\mathrm{P}$ \\
\hline \multirow{2}{*}{ Type (Level 2) } & \multirow{2}{*}{$\begin{array}{l}\text { Hydro-climatic } \\
\text { Conditions }\end{array}$} & Humid Climate & $\mathrm{H}$ \\
\hline & & Wet Subhumid Climate & $\mathrm{W}$ \\
\hline Subtype (Level 3) & $\begin{array}{c}\text { Zonal and } \\
\text { Intrazonal } \\
\text { Vegetation with } \\
\text { communities of } \\
\text { Classes: } \\
\text { Carpino-Fagetea } \\
\text { sylvaticae, Quercetea } \\
\text { pubescentis, } \\
\text { Robinietea, } \\
\text { Crataego-Prunetea, } \\
\text { Molinio- } \\
\text { Arrhenatheretea, } \\
\text { Festuco-Brometea } \\
\end{array}$ & & $\mathrm{V}$ \\
\hline \multirow[b]{3}{*}{ Genus (Level 4) } & \multirow{3}{*}{$\begin{array}{l}\text { Mezorelief } \\
\text { (including the } \\
\text { character of current } \\
\text { processes for the } \\
\text { formation of the } \\
\text { relief) }\end{array}$} & Denudation level without karst & $\mathrm{I}$ \\
\hline & & Denudation level with karst & II \\
\hline & & Erosional and Denudation levels & III \\
\hline \multirow{4}{*}{ Group (Level 5) } & \multirow[t]{4}{*}{ Rock Foundation } & Carbonate sedimentary rocks & $\mathrm{c}$ \\
\hline & & Non-carbonate sedimentary rocks & $\mathrm{n}$ \\
\hline & & Magmatic and metamorphic rocks & $\mathrm{m}$ \\
\hline & & Unconsolidated deposits & $\mathrm{u}$ \\
\hline \multirow{5}{*}{ Type (Level 6) } & \multirow{5}{*}{ Soil Type } & chromic Luvisols, LVx & 1 \\
\hline & & eutric Vertisols, VRe & 2 \\
\hline & & rendzic Leptosols, LPk & 3 \\
\hline & & albic Luvisols, $L V a$ & 4 \\
\hline & & luvic Chernozems, $\mathrm{CHI}$ & 5 \\
\hline \multirow{13}{*}{ Subtype (Level 7) } & \multirow{13}{*}{ Land cover } & $\begin{array}{c}\text { Artificial birch forests (Betula pendula Roth) } \\
\text { at the place of oak forests (Quercus sp.) and } \\
\text { beech forests (Fagus sylvatica } \mathrm{L} \text {.) }\end{array}$ & $\mathrm{bp}$ \\
\hline & & $\begin{array}{l}\text { Communities of the Fagetalia sylvaticae, } \\
\text { alliance Fagion sylvaticae }\end{array}$ & fs \\
\hline & & $\begin{array}{l}\text { Communities of the alliances Quercion } \\
\text { petraeocerridis and Carpinion betuli }\end{array}$ & cbqd \\
\hline & & $\begin{array}{l}\text { Communities of the alliances Quercion } \\
\text { petraeocerridis and Carpinion orientalis }\end{array}$ & coqp \\
\hline & & $\begin{array}{l}\text { Coniferous forests (Pinus sylvestris L.; Pinus } \\
\text { nigra Arnold; Picea abies (L.) Karst.; } \\
\text { Pseudotsuga menziesii ssp menziesii) }\end{array}$ & pin \\
\hline & & $\begin{array}{l}\text { Communities of the alliance } \\
\text { Quercion confertae. }\end{array}$ & qcqf \\
\hline & & $\begin{array}{l}\text { Deciduous forest with non-native species } \\
\text { (Quercus rubra L.; Robinia pseudoacacia L.) }\end{array}$ & inv \\
\hline & & $\begin{array}{c}\text { Communities of the alliance Berberidion } \\
\text { vulgaris }\end{array}$ & cmps \\
\hline & & $\begin{array}{l}\text { Pastures and Meadows of the classes Molino- } \\
\text { Arrhenatheretea and Festuco-Brometea }\end{array}$ & pame \\
\hline & & Quarry & quar \\
\hline & & Anthropogenic territories & antr \\
\hline & & Agricultural areas & agri \\
\hline & & Water bodies & wat \\
\hline
\end{tabular}




\section{Lithology}

The layer is based on a geologic map of the area in M 1:100 000. The lithological diversity is plentiful so the different types of rocks were combined into four groups, based on their chemical composition and formation. These groups are as following: carbonate sedimentary rocks, consisting of aphanitic, nodular and massive organogenic limestones and dolomitic limestones; noncarbonate sedimentary rocks, built up by conglomerates, breccia-conglomerates, sandstones, siltstones and coal; unconsolidated deposits with boulders, pebble and sands in it and magmatic and metamorphic rocks, consisting of metamorphosed shales, lidites, marbles, spilites, keratophyres, volcanics hornblende andesites, trachyandesites, andesitobasalts in extrusive, explosive and subvolcanic facies. The largest share of landscapes are those on carbonate sedimentary rocks and they take up to around $65 \%$ of the whole territory. These landscapes are situated mainly in the northern and central parts of Dragoman Municipality, covering areas in the mountains of Chepan, Mala Planina and Burel Valley. Non-carbonate sedimentary rocks $(11,9 \%)$ and magmatic and metamorphic rocks $(16,8 \%)$ take up almost an equal share of the whole territory. Landscapes, built with the first group of rocks are located in the southwestern corner of the municipality near the villages of Chekanets, Gorno selo, Yalbotina. Landscapes with magmatic and metamorphic rocks are situated in two bands with north-western to south-eastern orientation around the villages of Dreatin and Nedelishte and Vishan, Vladislavtsi and Chorul. Last, but not least, the unconsolidated deposits are located in the central parts of Dragoman Municipality mainly in the area surrounding Dragoman Marsh. They cover $6,3 \%$ of the investigated area.

\section{Relief}

The georeferenced layer with the relief features of the municipality was built by using a database with the contemporary relief forming processes. A topographic map of the area with a scale M 1: 25 000 was applied as a basis for the distinguishment of three types of landscapes: on denudation levels with karst, on denudation levels without karst and on erosional and denudation landscapes. The morphometric parameters of ASTER GDEM were also applied, during the preparation of the layer.
Erosinal and denudation levels cover the largest proportion of the area and they take up to $53,8 \%$ of the territory. They are situated in the northern, central and southern territories. Next are landscapes on denudation levels with karst (26,8\%), typical for the mountains of Mala Planina and Chepun and landscapes on denudation levels without karst $(19,4 \%)$ are covering mainly an area in the form of the letter " $\mathrm{C}$ " to the south around the villages of Tsatsarovtsi, Yalbotina and Chukovezer.

\section{Climate}

The climatic layer was developed, using the information, published by Topliisky [16] and Borissova et al. [4] and so the humidity index of Thorntwaite [14] is applied for the classification of the climate in Dragoman Municipality. The territory of the municipality is divided by landscapes with humid climate and landscape with wet subhumid climate. The first group takes the largest proportion of the area $-80,5 \%$, while the wet subhumid landscapes are situated only the southwestern corner near the villages of Dreatin, Krusha, Chekanets, Tsatsarovtsi and they cover $19,5 \%$ of Dragoman Municipality.

\section{Soils}

Soils, as a landscape forming factor, were investigated by using a soil map of Bulgaria with a scale M 1:400 000. The edaphic factor was then analysed and a few soil types were derived. Among them are Rendzic Leptosols, LPk, which are typical for the karst landscapes in the north and east. They cover $42,5 \%$ of the territory of Dragoman Municipality. Chromic Luvisols, LVx (29,3\%) are an integral part of landscapes in the western and southwestern parts of Dragoman Municipality. Covering almost the same areal proportion, eutric Vertisols, VRe, are located mainly in the southern parts and they take up to $24,9 \%$ of the area. Albic Luvisols, Lva (1,7\%) and luvic Chernozems, CHI $(1,6 \%)$ are covering the smallest areas, considering territorial extent, located in the remotest northeastern corner and around Dragoman Marsh, respectively.

\section{Land cover}

The layer with the land cover types of Dragoman Municipality was derived from the Forestries of 
Sofia and Slivnitsa and revised, following the terrain research. 21 land cover types were distinguished, including broad-leaved forests (26,2\%), consisting of forests, dominated by Carpinus betulus L., Quercus dalechampii Ten., Fagus sylvatica L., Quercus pubescens Willd., Quercus cerris L. The artificial coniferous forests (Pinus sylvestris L., Pinus nigra Arnold, Pseudotsuga menziesii ssp menziesii) are building up another land cover type and they take up to $18,2 \%$ of the area. Pastures and meadows take up to $26,4 \%$ of Dragoman Municipality. Non-native species, such as Robinia pseudoacacia L. and Quercus rubra L. cover $0,9 \%$ of the area. Anthropogenic territories (11,5\%), quarries (1,2\%), water bodies and agricultural areas (15,5\%) are forming the other land cover types. The development of the final landscape map was accomplished by combining all of the above layers, representing major landscape components. As it was mentioned above, every generalized level in the classification category has its unique code symbol, put in the factors and criteria for landscape classification and differentiation. Its use is unavoidable in order to have a readable landscape map, because of codes were omitted, every landscape would have a long scientific name, which would be inappropriate if put in the legend. If this is to be illustrated with an example - the mountainous landscape with humid climate, located on erosional and denudation level with carbonate sedimentary rocks, on chromic Luvisols, LVx with agriculture, as it can be seen here, takes almost two rows, while its code symbol is simply MHIIIc1 agri. The presented landscape map of the studied object (Fig. 2) and its legend (Fig. 3) display the abundance of 199 landscapes in Dragoman Municipality.

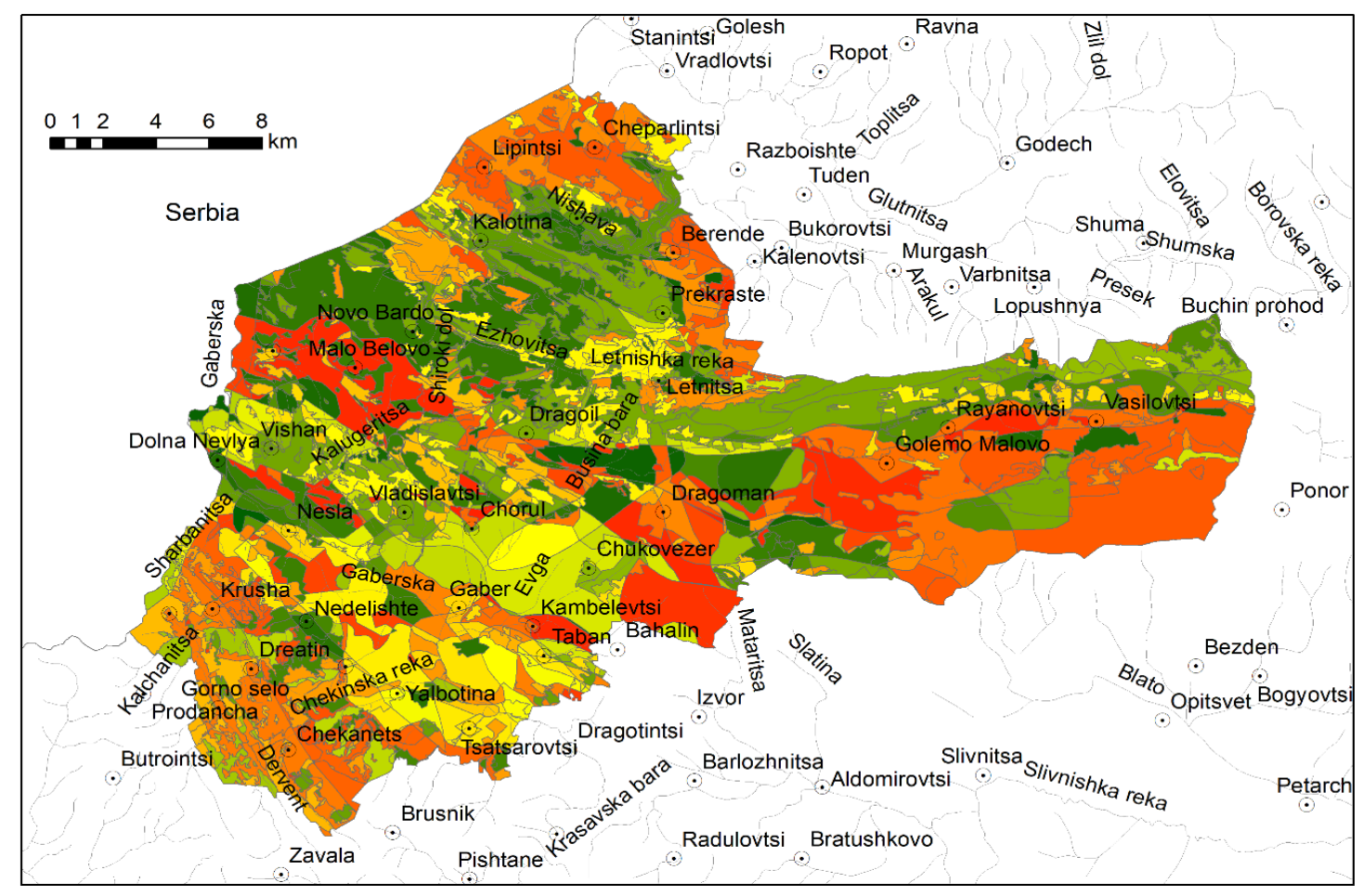

Figure 2. Landscape map of Dragoman Municipality

The legend is divided from the map in order to get a better understanding of it. By far landscapes with code name MHIIc3pame. They cover $8,6 \%$ of the investigated area and can be found near the villages of Golemo Malovo, Vasilovtsi and Rayanovtsi to the east and Lipintsi and Cheparlintsi to the north. MHIIIc3qcqf landscapes are next in line. They take up to $6 \%$ of the area and are located mainly to the north near the villages of Kalenovtsi, Prekraste and
Novo Bardo. MHIIIc3pame landscapes are covering $5,4 \%$ of the territory and are mainly situated between the villages of Rayanovtsi and Letnitsa to the northeast. MHIIu2agri and MWIm1pin are the ones with the smallest proportion. They account for less than $0,0001 \%$ and are situated to the northeast of the village of Krusha and to the east of Dragoman city, respectively. 


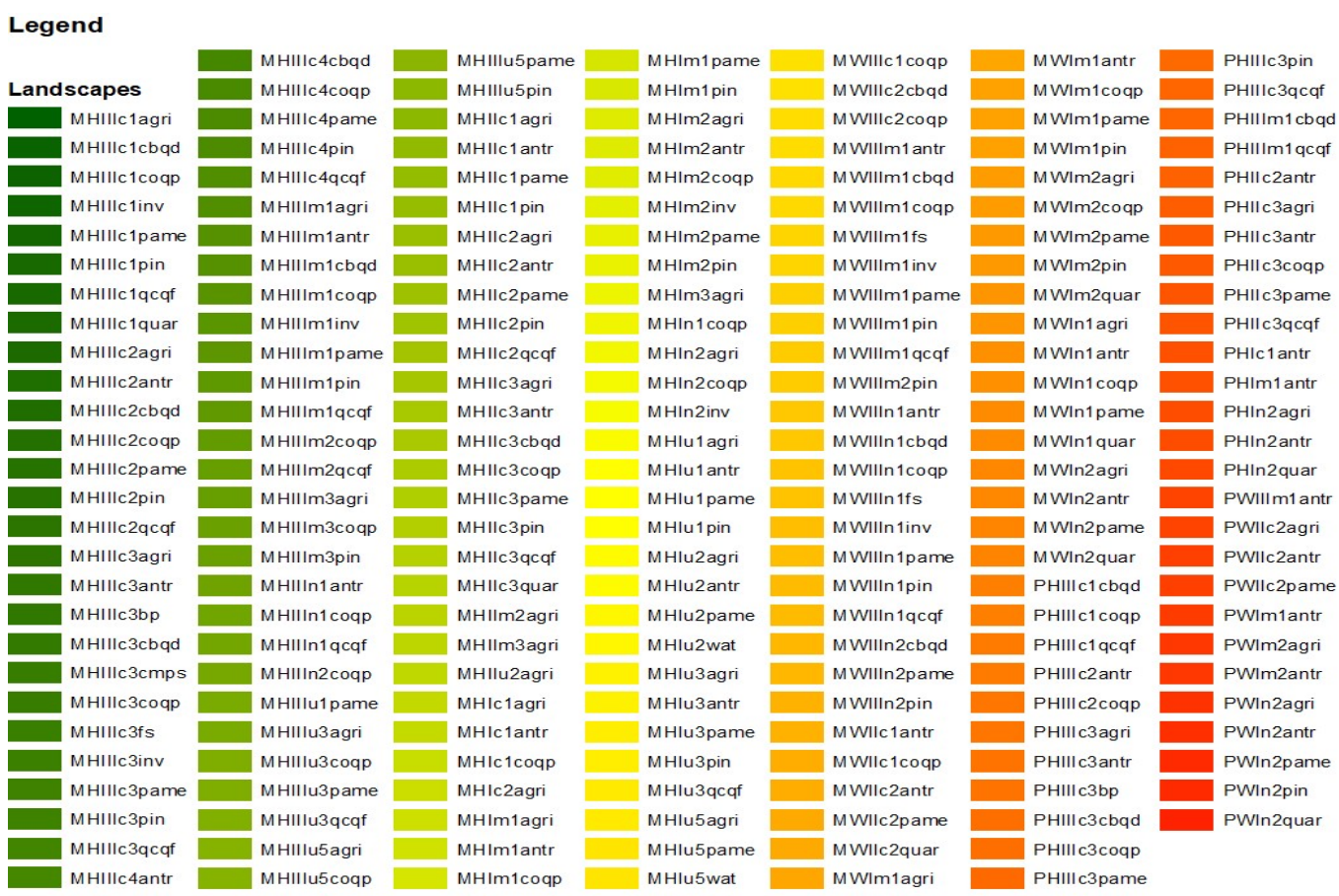

Figure 3. The legend of the Landscape Map

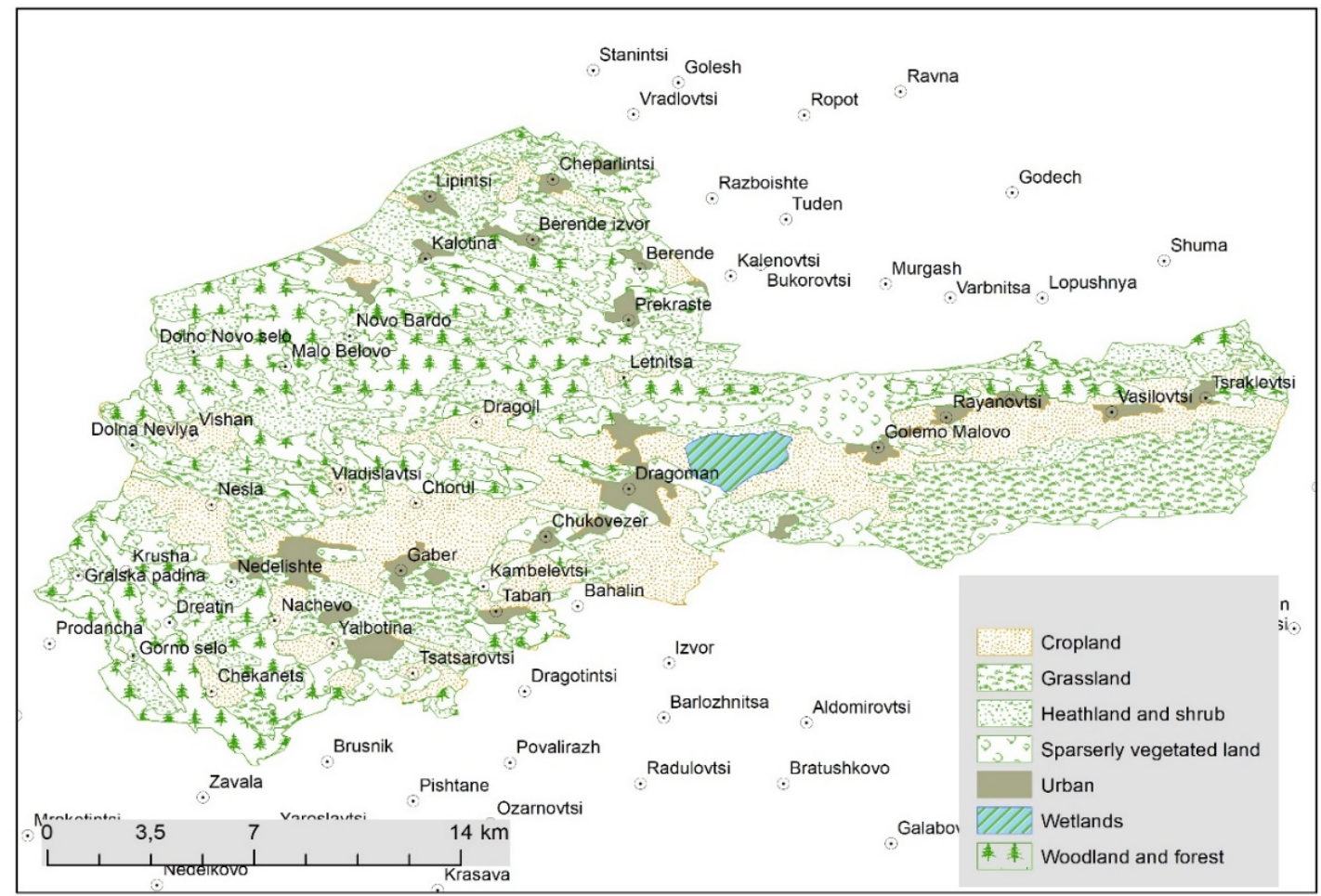

Figure 4. Ecosystem types of Mala Planina according to MAES typology.

\section{Ecosystem types}

The territory of Dragoman Municipality is a representative for all ecosystem types at level 2 of the MAES Typology (Figure 4). The area of Dragoman Municipality is being presented by a total number of seven ecosystem types: cropland, grassland, heathland and shrub, sparserly vegetated land, urban, wetlands and woodland and forest and they follow the geographical distribution, discussed in the aforementioned part with the landscape diversity. It can be pointed out with a great certainty the there is an indivisible integrated connection between the landscapes and the ecosystem types in the investigated area. The difference between them is the distinct approaches for their investigation, although in the end they turn out to represent equal features. 


\section{CONCLUSION}

The current research represents a continuation of the landscape investigation of Western Stara Planina and Mala Planina in particular. By broadening the geographical coverage to the west, reaching the borderline with the Republic of Serbia, we managed to receive a broader perspective from a landscape point of view. The total number of 199 landscapes in Dragoman Municipality is a proof for a high landscape diversity in the region. The combination of the landscape components of lithology, relief, climate, soils and land cover lead to an abundant units of landscape differentiation. At the same time, the investigated ecosystem types show an indivisible integration with the landscapes, regarding their geographical distribution and characteristics. The application of the methodologies proved successful once again and they may be used for another continuation in this respect and as a basis for other similar investigations.

\section{ACKNOWLEDGMENTS}

This investigation was carried with the financial help of the national scientific programme "Young scientists and Postdoctoral students” for 2019, contract № 22-0078/ 22.04.2019.

\section{REFERENCES:}

[1] Borissova, B., A. Kotsev, 2012. Landscape Character Typologization and Mapping of the South Bulgarian Black Sea Coast: The Case Study of the Strandzha Nature Park. In: "Environment and Ecology in Mediterranean Region", Cambridge Scholars Publishing.

[2] Borissova, B., E. Tsambova, 2012. Evaluation of the Landscape and Ecological resources of Natural Park "Belasitsa" for recreational and touristic needs. Yearbook of SU, Book 2, Geography, 105, $213-234$ (in Bulgarian).

[3] Borisova, B., A. Assenov, P. Dimitrov, 2014. A New Approach for Landscape Ecological Research in Mountain Areas. Seminar of Ecology - 2014. Sofia.

[4] Borissova, B., A. Assenov, P. Dimitrov, 2015. The Natural Capital of Selected Mountain Areas in Bulgaria, pp. 91108. In: M. Luc, U. Somorovska, J. Szmanda (eds.) Landscape Analysis and Planning, Springer.

[5] Cholakova, Z., 2016. Landscape-Geochemical Investigations of the Basin of Iskar River between the cities of Novi Iskar and Mezdra. Dissertation, Sofia (in Bulgarian).

[6] Grigorov, B., A. Assenov, 2019. Landscape Diversity of Mala Planina. Yearbook of SU, Book 2, Geography, 111, 103-115.

[7] Konteva, M., 1992a. Landscapes on the southern slope of Berkovska Planina. Yearbook of SU, Book 2, Geography, 84 (in Bulgarian).

[8] Konteva, M., 1995b. Landscapes of Vidlichko-Visochka Stara Planina. Yearbook of SU, Book 2, Geography, 82 (in Bulgarian).

[9] Konteva, M., 1992c. Factors for Landscape Formation of Zaburge. Yearbook of SU, Book 2, Geography, 81 (in Bulgarian).

[10] Maes J., A. Teller, M. Erhard, et al. (2013). Mapping and Assessment of Ecosystems and their Services. An analytical framework for ecosystem assessments under action 5 of the EU biodiversity strategy to 2020. Publications office of the European Union, Luxembourg.

[11] Maes J., A. Teller, M. Erhard, et al. (2014). Mapping and Assessment of Ecosystems and their Services. Indicators for ecosystem assessments under Action 5 of the EU Biodiversity Strategy to 2020. Publications office of the European Union, Luxembourg.

[12] Nedkov, S., S. Bratanova-Doncheva, B. Markov (2017). Mapping of ecosystems in Bulgaria based on MAES typology. In - Chankova, S. \& al. (eds) Proceedings of Seminar of Ecology-2016 with international participation. FARAGO, 182-189.

[13] Popov, A., 2001. Geoecological Classification of landscapes in Bulgaria. Main Approaches and Principles. Yearbook of SU, Book 2, Geography, 91, 27-38 (in Bulgarian). 
[14] Thornthwaite, C., 1948. An Approach toward a Rational Classification of Climate. Geographical Review, Vol. 38, No. 1., pp. 55-94.

[15] Todorov, N., A. Velchev, 2014. Landscapes of Bulgaria - Spatial Structure, "IVIS”, Veliko Tarnovo, 126 pp. (in Bulgarian).

[16] Topliisky, D., 2006. Drought in Bulgaria Based on Thornthweite's Classification Scheme. Second International Scientific Conference Global Changes and New Challenges of 21Century. 22-23 April. Sofia.

[17] Velchev, A., R. Penin, N. Todorov, M. Konteva, 2011. Landscape Geography of Bulgaria. BULVEST 2000, Sofia, 235 pp. (in Bulgarian).

[18] Wascher, D. (ed). 2005. European Landscape Character Areas - Typologies, Cartography and Indicators for the Assessment of Sustainable Landscapes. Final Project Report as deliverable from the EU's Accompanying Measure project European Landscape Character Assessment Initiative (ELCAI), funded under the 5th Framework Programme on Energy, Environment and Sustainable Development (4.2.2), $\mathrm{x}+150 \mathrm{pp}$.

[19] https://land.copernicus.eu/pan-european/corine-land-cover/clc2018 